\title{
More doctors talking about nonclinical careers, but challenges remain
}

Cite as: CMAJ 2018 August 13;190:E969-70. doi: 10.1503/cmaj.109-5618

Posted on cmajnews.com on July 25, 2018.

W hen Dr. Melissa Yuan-Innes finished her residency, as her peers were busy applying for jobs and snapping up locum shifts, she decided to limit her clinical work to make time to write. Her peers were incredulous.

"It was a really bizarre thing to do," she says. "I think nowadays, people are given a little bit more latitude in what's considered normal."

Yuan-Innes has been practising parttime at two emergency departments for the past 15 years. The schedule gives her time to pursue her other passion: writing mystery novels and nonfiction under the pen name Melissa Yi.

"As medicine becomes less creative and we follow a lot of algorithms and guidelines, physicians like myself want to do things that have our own stamp on them," she says.

It's difficult to quantify how many Canadian doctors are moving into other careers, whether full-time or part-time. The Canadian Medical Association doesn't have data on doctors who leave medicine to pursue other careers; doctors who give up their licences are counted as retired.

A recent survey of US physicians, however, found $2 \%$ of respondents planned to pursue careers outside medicine.

One thing is sure: more doctors are talking openly about other lines of work. "It could be this generation is just more free and open," says Dr. Heidi Moawad, a neurologist and author of Careers Beyond Clinical Medicine. Several forums and websites have emerged in the last few years for doctors seeking nonclinical careers.

In the US, popular nonclinical options include working in insurance or pharmaceuticals, where "a doctor's experience adds a lot," says Moawad, who manages nonclinicaldoctors.com. Other MDs pursue careers far from medicine. "Some people will go and open a store or do something creative."

As to why doctors go into nonclinical careers, "some are just fed up with medicine" says Moawad. "But a lot of the time, they had another interest that wasn't really explored in the first place."

That was the case for Dr. Seema Marwaha, who divides her time between internal medicine, research and journalism. "I started med school when I was 20. I was involved in documentary film and taking sociology classes and then I was thrown into this really intense scientific, academic program," she says.

When Marwaha finished her residency, she picked up the interests she had put aside, which led to a journalism fellowship and dozens of photography, video and journalism projects. "I don't want to put myself in square hole if I'm a round peg."

She's had to find mentors outside medicine and work on projects in her spare time. It hasn't been easy. Senior doctors have given her advice like, "You can do this journalism fellowship but it might impact your ability to ever work in a downtown academic centre." But Marwaha is convinced her research and media pursuits benefit her clinical work, and vice versa. She's currently studying how patient testimonies posted online can help health professionals better understand patient perspectives.

Dr. Joshua Tepper, president and CEO of Health Quality Ontario, an arms-length agency of the Ontario government,

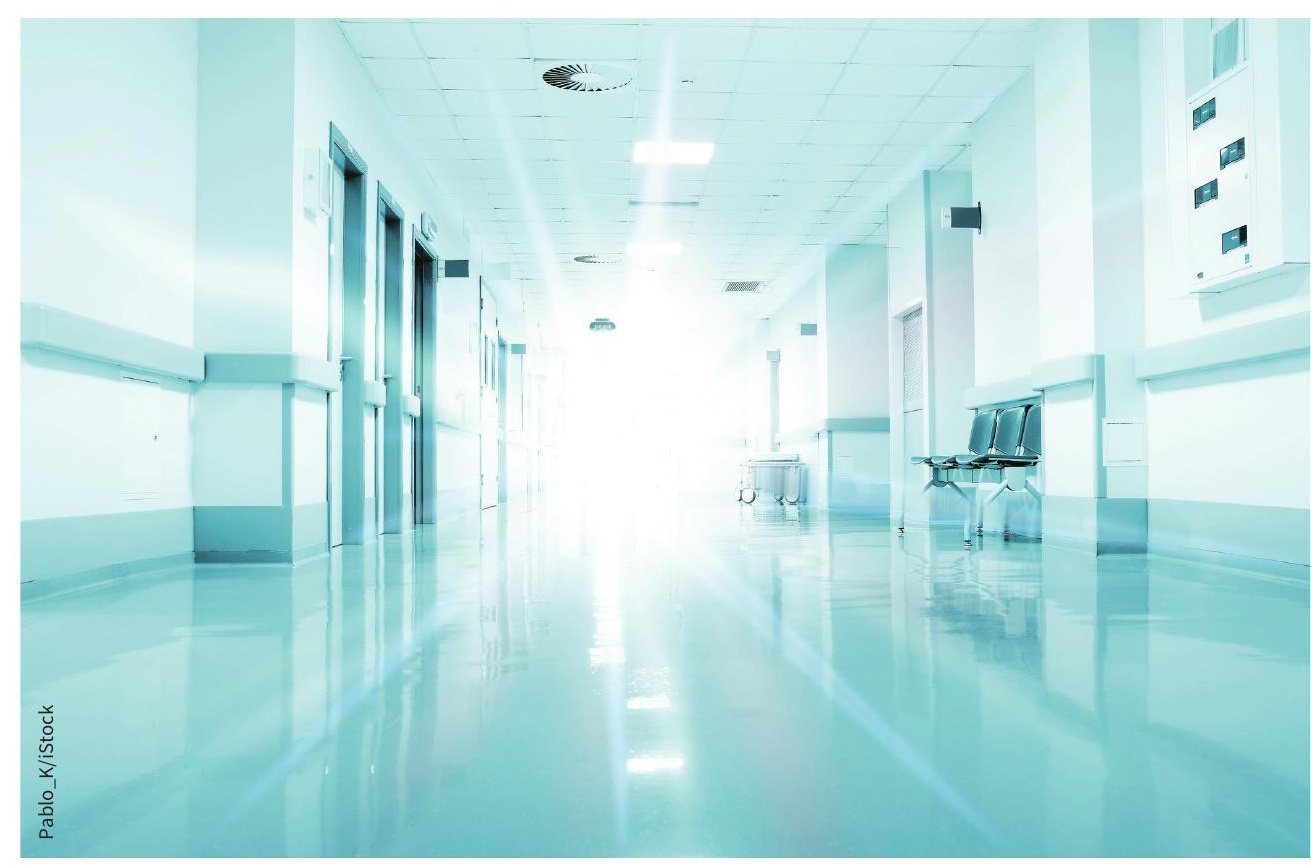

Doctors interested in work outside clinical settings end up in various fields, including insurance, pharmaceuticals and research. 
pursued policy work to serve his patients in a way he couldn't as a front-line physician. "Doing a lot of inner city, rural, remote medicine, there were many times where what I could do for a patient was limited by the broader system structure," he says.

He still works at least half a day a week at a family practice and one evening weekly at a clinic for homeless men. He often brings up his interactions with patients in system-level meetings and discussions. Many of the skills he learned in medicine have transferred to his new role. "Communicating, engaging and listening attentively - all those things we get taught - are really useful working with a wide variety of people on complex problems."

Marwaha adds that her medical training taught her "to be efficient ... and get the job done no matter what." In slowerpaced fields, doctors can be "really ambitious and hyperproductive."

It's common for doctors pursuing other interests to continue to moonlight with locums, says Moawad. One of the biggest barriers to career change is a physician's fear of being unable to go back to medicine. In many jurisdictions, doctors need to continue to practice to retain their licences.

Tepper says his clinical work has come at the expense of "time with friends and family and sleep," but he couldn't imagine giving it up. "Being a physician is very much part of my identity, and something I take tremendous pride and satisfaction in."

Wendy Glauser, Toronto, Ont. 